\title{
Think twice!
}

\section{Grænser og kategorier i opbrud}

I Danmark bor asylansøgere $i$ lejre. De forste indtryk af asylansøgeres liv byder pai tresteløse billeder af andetgørelse, institutionalisering og afvikling af mennesker. Men sporger man unge asylansøgere selv, bringer de ogsai en rakke andre reprasentationer til torvs. Herigennem forsoger de at overskride den andethed og ulighed, der som en folge af den danske asylpraksis, bliper de "etniske andre" til del. $\tau$

begyndelsen af 1995 introducerede jeg en gruppe unge asylansøgere for en ide om, at de skulle indfange deres hverdagsliv i et kameras linse. ${ }^{1}$ De unge medforskere skulle bidrage til et forskningsprojekt med deres egne perspektiver på livet i en multietnisk asyllejr. ${ }^{2}$ Deltagerne skulle tage billeder af noget, som kunne fortælle, hvordan det var at bo i netop dette børne- og familiecenter, og hvilke praksisser og identiteter, der kom til udtryk.

Og det gjorde de så. Der blev taget billeder af børn i aflagt tøj, af tilhyllede kvinder og hele familier installeret på en sofa. Af fædre, der bare "hang ud", af triste og ensomme unge, af slagsmål og snavsede storkøkkener. I billederne sås konturene af isolation, afmagt og marginalisering. Det var mennesker i limbo og i psykisk afvikling, der blev affotograferet. Det var nøjagtig så trøstesløst, som jeg havde forestillet mig efter mine indledende forberedelser til projektet. De første måneders intense deltagerobservation samt mine første analyser af 


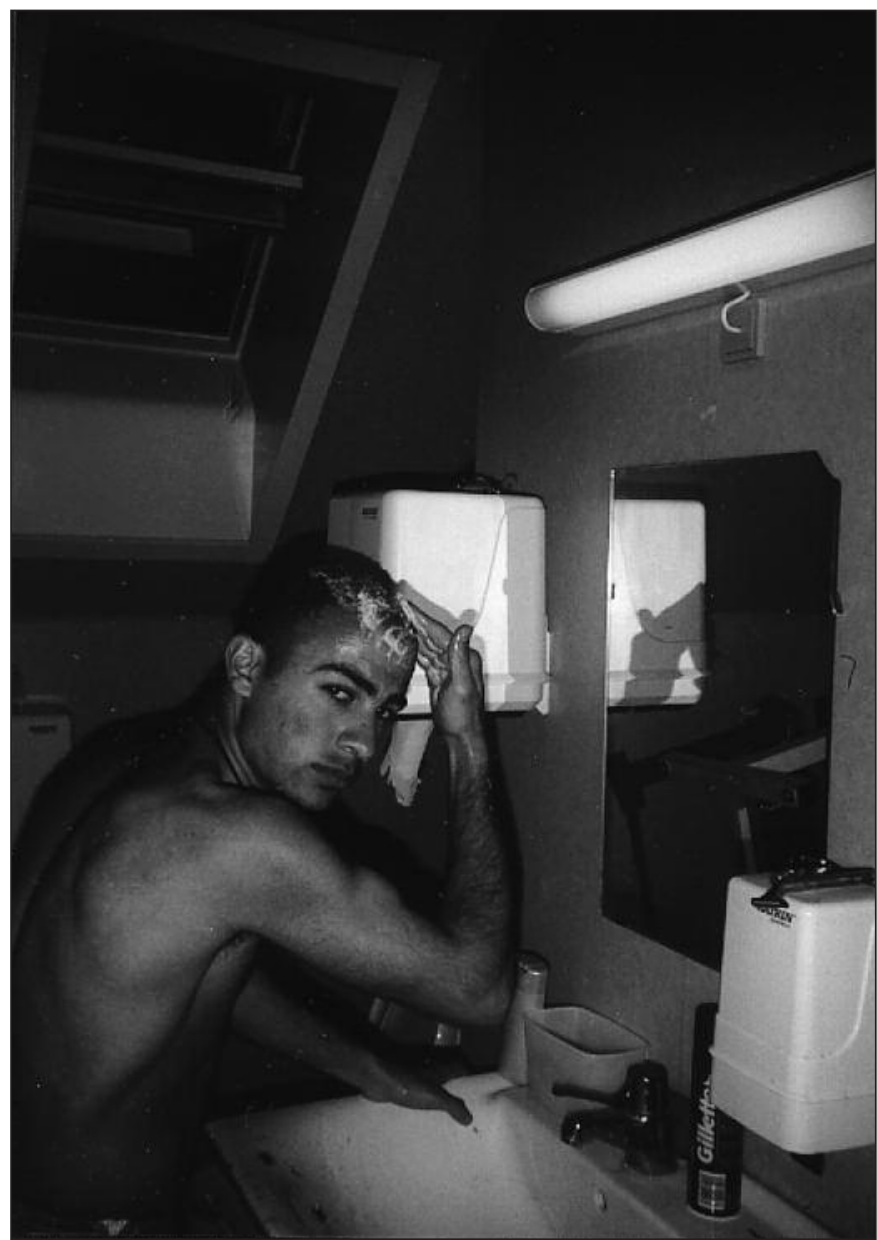

den danske asylpolitik og det konkrete centers strukturer havde peget på en kontekst, hvor midlertidighed og uvisheden om fremtiden var et grundvilkår, og hvor andetgørelse, marginalisering og umyndiggørelse af asylansøgerne var allestedsnærværende.

Men en del af de unges billederne gengav hverken mine skrivebordsfantasier eller mine deltagerobservationer. Gang på gang vakte billeder undren. Hvad havde opstillede turistbilleder i Frederiksberg Have eller på Rådhuspladsen med hverdagslivet i asyllejren at gøre? Hvorfor var der serier af de unge portræetteret foran naboejendommen, der var forbeholdt bosniske flygtninge? Hvorfor var der så mange (selv)portrætter? Hvorfor blev der i flere serier hele tiden skiftet tøj, barberet hovedbund eller foretaget andre ændringer på kroppens overflade? Medforskerne udfordrede min forståelse og de repræsentationer, jeg havde af asylansøgere.

Uoverensstemmelsen mellem mine forhåndsantagelser og motiverne på de fremkaldte billeder tilskrev jeg i første omgang min kommunikation med fotograferne. Når de unge gjorde noget andet, end det jeg havde forberedt mig på, havde jeg nok ikke formidlet ideen klart nok. Derfor hev jeg et arsenal af kultur- og sprogmødeteorier frem, der skulle pege på de kulturelle forskelle som problemets kerne (Staunæs 1997). Jeg forsøgte at forklare ideen for medforskerne igen og igen. Men de unge var 


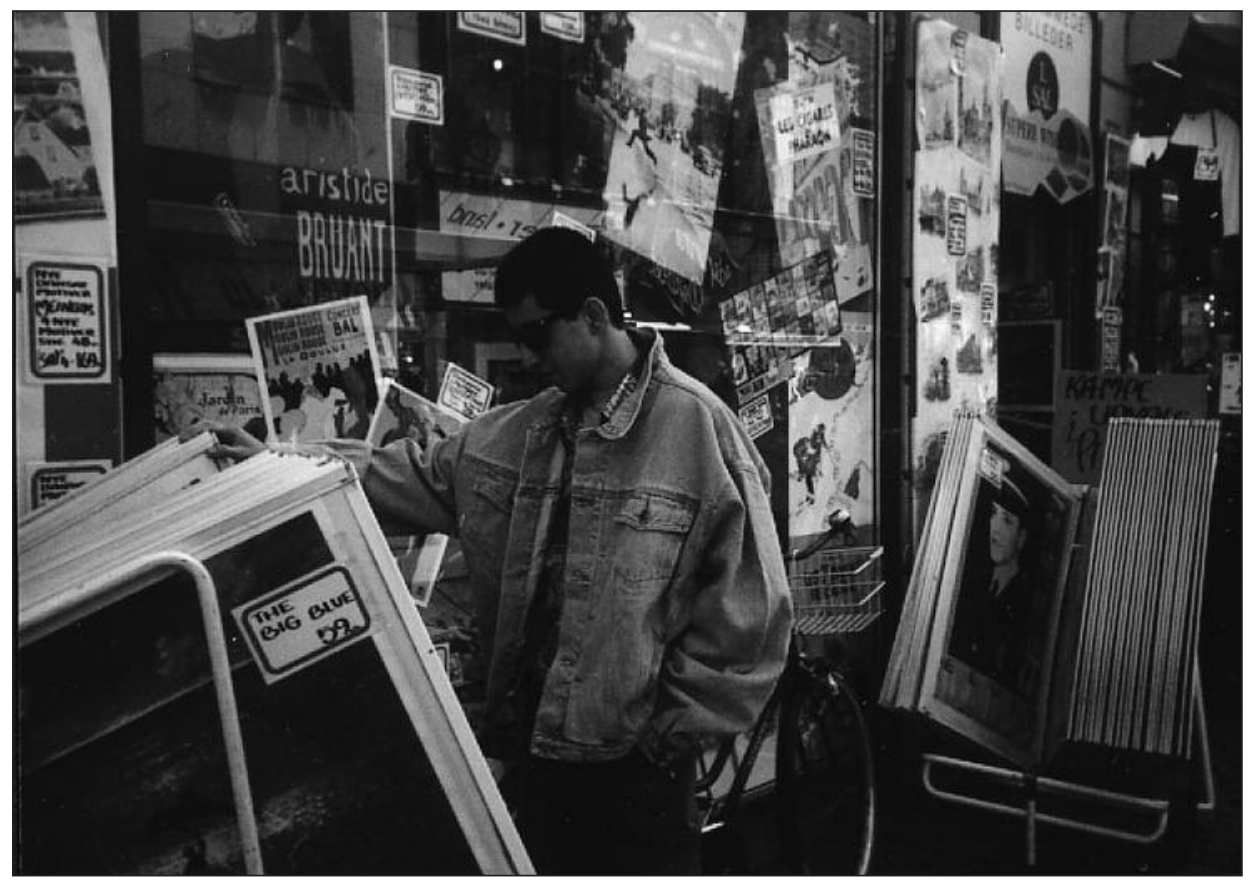

hver gang af den overbevisning, at de havde forstået tanken om fotografering af hverdagslivet. Efterhånden gik det op for mig, at det vist snarere var mig selv, der ikke havde forstået hverdagslivet og ikke havde taget min egen teoretiske og metodiske tilgang alvorligt; at uanset, hvad billederne forestillede, har fotograferne grunde til den fremstilling. Grunde som måske kan forstås ved at nærlæse fotografens (aktørens), fotograferingens (den sociale praksis) og perspektivets kontekst (asyllejren).

Min undren skyldes ikke, at billedemotiverne ikke passede ind i mine forestillinger om mennesker med en "anden” etnisk baggrund. Jeg havde og har ikke et tableau over essenser placeret inde i sorte mennesker eller mennesker med en "anden" etnisk baggrund. Min overraskelse skyldtes derimod, at jeg ikke kunne få motiverne til "at passe ind" i en asyllejrkontekst. ${ }^{3}$ Asyllej- ren er en kontekst, hvor de samfundsmæssige og institutionelle betingelser, der bliver de "etniske andre" asylansøgere til del er meget restriktive og deformerede, hvorfor jeg havde en forventning om at se mennesker i konstant afvikling. Med børnenes og de unges nye bidrag blev det analytiske omdrejningpunkt nu at gentænke mit perspektiv: Var det alligevel muligt at imødegå institutionaliseringen, at udvikle sig i asyllejren, og ikke bare reducere sit handlerepertoire? Og i givet fald på hvilken måde spillede udviklingsprocesserne sammen med og på tværs af sociale kategorier som køn og etnicitet samt med længden af lejropholdet?

NyE REPRÆSENTATIONER AF DE "ETNISKE ANDRE"

Som forsker kan man se sig blind på de psykosociale lidelser, der uværgeligt finder 
sted, når handlesammenhængen er så deformeret, som det er tilfældet i en asyllejr. Man kan anlægge et elendigheds- og offerperspektiv, som det har været toneangivende i dansk indvandrer- og flygtningeforskning gennem flere år (Mørck 1998), og man kan vælge at skrive videre på Det store Bekymringsnarrativ om de "etniske andre" (Staunæs 1998a). Problemet er, at disse tilgange ofte fastholder en andetgørelse af de ikke-danske. De bliver ved med at være de "Andre". De unormale. De, der ikke er subjekter eller aktører, men derimod passive objekter. Det kan tendere til kulturel racisme og til, at man legitimerer kulturel racisme ved at opretholde de dominerende representationsregimer. Det er vigtigt at fă etableret dialogen med de udforskede og lade andre repræsentationer få spalteplads. Det er derfor min ide med denne artikel at belyse de andre representationer, de unge udarbejdede som led i forskningsprojektet, og som viser brud med etablerede kategorier, grænser og andethed.

Jeg vil hverken fornægte den menneskelige elendighed eller afvikling, der fandt sted i asylcentret. Det har jeg skildret andetsteds (Staunæs 1998b). Men her vil jeg fokusere på udvikling og på, hvordan de unge asylansøgere $\mathrm{i}$ deres hverdagsliv forsøgte at overskride den andethed og ulighed, man mødes med som asylansøger. Jeg vil se på, hvordan deres praksisser kan forstyrre lukkede sociale kategorier som etnicitet og køn. Hvordan de kan udfordre etablerede positioner for henholdsvis unge mandlige og kvindelige asylansøgere. Hvordan de unge mænd og kvinder udvikler praksisser, der indebærer andre livsmuligheder og andre identiteter end de, der forbindes med asylansøgere fra tredjeverdenslande og på, hvordan disse processer konstitueres af og er konstituerende for kategorier og positioner bundet op om etnicitet og køn.

\section{EN IKKE HELT ALMINDELIG TID I ET IKKE HELT ALMINDELIGT RUM}

Ved at studere de koder, der ligger i asyllejrens placering og arbejdets organisering er det muligt at skitsere en dominerende diskurs og praksis i forhold til de unge asylansøgere. Det er betingelser, der gxlder alle asylansøgere men som stiller sig forskelligt for og kan håndteres forskelligt fra forskellige positioner.

For de asylansøgende unge er præasyltiden ikke en almindelig hverdag. I præasyltiden omkodes flygtningene fra alverdens steder til asylansøgere. Det er en omkodning, der sker på baggrund af en kategorisering som ikke-danske. Omkodningen sker gennem udskillelser og afgrænsninger: De făr taget fingeraftryk, får tildelt et registreringsnummer, gennemgår forhør og lægeundersøgelse. I præasyltiden interneres de i lejre. Lejrene har f.eks. til huse i nedlagte sygehuse og psykiatriske hospitaler, i skibe eller tidligere avlsbygninger. Formålet med lejrene er at opbevare asylansøgerne et eller andet sted, mens deres asylansøgning behandles men samtidig undgå, at de integreres. I lejren venter man på afgørelse af sin ansøgning og dermed på sin fremtid. I ventetiden må asylansøgerne ikke påtage sig lønarbejde, gå i dansk folkeskole, og de har ikke de statsborgerrettigheder, som den øvrige befolkning nyder. Det er, som det er beskrevet af flere forskere en limbotilstand, en mellemtid, et transitliv (f.eks. Bousquet 1987; Larsen 1995; Staunæs 1998b), hvor det midlertidige og uvisheden råder. Lejren udgør en konstant demonstration af deres andethed, udskilthed og placering i samfundets margin. Såvel praksisser som de tidslige og rumlige dimensioner tegnsætter asylansøgerne som "Andre", der ikke har samme rettigheder som de "etnisk danske". De "Andre" er udskud, der ekskluders fra et normalt liv (Harrel-Bond \& Voutira 1992).

I den asyllejr, jeg har forsket i, er beboerne børnefamilier samt børn/unge og deres ledsagere, dvs. børn/unge, der er ankommet hertil med en voksen, der ikke er deres 
forælder. For de unge har præasyltiden varet fra 3 mdr. til 4 år. Det er ret lang tid i ethvert liv, men måske særligt i en ung eller barns. I denne lejr har ventetiden en ganske særlig udformning, idet den foregår indvævet i en professionel praksis. Centret kan forstås som en institutionslignende foranstaltning på trods af, at beboerne ikke per defintion er behandlingskrævende f.eks. fysisk eller psykisk syge. Børne- og familiecentret kan med Erwing Goffmans (1961) begreber forstås som en social hybrid mellem beboelse og professionel praksis, som en total institution, hvor uligheden mellem dansk førstehed og etnisk andethed er strukturelt indbygget. Totaliteten og den strukturelle ulighed ses for det første gennem afskærmning $\mathrm{i}$ forhold til det øvrige samfund og for det andet i, at der foregår en overordnet styring af beboernes hverdag. Styringen foregår gennem en professionel praksis, der varetages af Dansk Røde Kors. Den professionelle praksis baserer sig på skellet mellem de "etnisk danske" og de "etniske andre" og dermed også på et "Herre i eget hus princip". Det betyder, at de "etniske danske" er herren i huset, hjælperen, der definerer problemer og tager beslutninger. Den hjulpne, den "etniske anden" må så indordne sig og modtage hjælpen med taknemmelighed og bøjet nakke (de Voe 1981; Osterkamp 1990). Den forskel tegnsættes og opretholdes gennem en række helt konkrete praksisser i børne- og familiecentrets hverdag: I Udlændingeloven er Røde Kors -arbejdet defineret som en indkvarteringsopgave, men i børne- og familiecentret er centermedarbejderne i højere grad blevet socialarbejdere, der skriver cardex, igangsætter aktiviteter, yder psykosocial støtte og leverer forskellige servicer, f.eks. udbetaling af lommepenge og udlån af støvsugere (mod aflevering af identifikationskort). Endvidere er der ansat særligt uddannede medarbejdere til at foetage psykologiske vurderinger, tilse asylansøgernes helbred og lede et pædagogisk arbejde for børnene og de unge.
Den andetgørende sondring mellem ansatte og beboere viser sig på forskellige planer. På det symbolske plan ses forskellenes koder i, at personalet skal bære et synligt ID-kort, så "beboerne kan skelne centerpersonale fra asylansøgerne” (Dansk Røde Kors' Centerhåndbog, bind 1, blad 17). På det sociale plan kommer den skarpe afgrænsning til udtryk i et forbud mod privat omgang mellem personale og beboere. Et forbud man håndhæver ved at henvise til overordnede principper om upartiskhed og neutralitet. Det er et forbud, som under ingen omstændigheder kan overskrides uden følger for medarbejderens ansættelse. På det organisatoriske niveau afspejles asymmetrien i placeringen og graden af ansvar, myndighed og magt. Det afspejles i forskellige positioner, handlemuligheder og i arbejdsopgavernes fordeling, hvor personalets travlhed står i skærende kontrast til beboernes “dagdriveri”. I modsætning til beboerne opererer personalet med en otte timers arbejdsdag og er socialt integrerede i verden udenfor.

Magten er indlejret i personalets positioner og arbejdsredskaber. Det overordnede ansvar og den overordnede myndighed centreres om personalet. Det ses f.eks. i, at man skal spørge sin kontaktperson om lov til at forlade lejren i mere end 24 timer. Uanset om man er barn, ung eller voksen. Den ansvarsfordeling giver associationer til et kernefamiliemønster (Andersen \& Agger 1991), hvor voksne klienter/beboere ligesom børn må overlade deres suverænitet til forældrene, til personalet. I asyllejren er personalet forældrene, der har myndigheden til at træffe beslutningerne, og alle asylansøgerne positioneres uanset alder som umyndige børn. Magtens fordeling og overvågning viser sig f.eks. i en døgnbemanding, der kan sikre en (døgn)overvågning. Hvis beboerne er væk fra centret i mere end 24 timer og ikke har faet lov til at tage på ferie eller lignende, skal centermedarbejderne underrette politiet. På helt lokalt niveau vises kontrollen og overvågnin- 
gen i personalets walkie-talkie, der medbringes overalt, i at der føres cardex og vagtbog. "Det er som et fengsel!", udbrød 17-årige Haroun spontant, da jeg spurgte ham om, hvorfor han ikke brød sig om at bo i lejren.

I det meste socialarbejde er der indlejret en dobbelthed om hjælp/støtte og kontrol. Men undertiden er det som om kontrol- og overvågningsaspektet får overtaget i asyllejren. Organiseringen af præasyltiden leder mine tanker hen på det overvågningssystem, panoptikon, Michel Foucault har beskrevet (Foucault 1979). Panoptismen er udtryk for en hierarkiseret, lokaliserbar og individualiseret struktur, hvori det er muligt at gennemlyse og kontrollere den enkelte uden at ty til vold eller fysiske overgreb.

Selv på den yderst spids af afmægtigheden har man mulighed for at handle og forholde sig til sine betingelser. Trods sin position i samfundets margin, er det umuligt at vælge ikke at handle eller ikke at forholde sig. Som mennesker kan vi ikke nægte at deltage i vores liv, fordi vi ikke synes om det. Det er, som man siger, "the only show in town", og vi afhænger i bogstaveligste forstand af det (Tolman 1994). De asylansøgende unge må altså forholde sig til de andetgørelser og grænsedragninger, der finder sted i såvel den nationale lovgivning som i den professionelle praksis. Hvilke forhandlingsindlæg, de kan tage i brug, er betinget af handlesammenhængen og af de positioner, de unge opnår der. Det er dermed ikke muligt at hive konstruktioner ind fra højre og venstre uagtet konteksten. I det følgende belyser jeg en bestemt del af forhandlingsindlæggene; nemlig de indlæg, der bringer grænser og kategorier i opbrud. De måder, hvorpå de unge kvinder og mænd forsøger at genindsætte sig selv som subjekter i deres liv og genforhandle den andetgørelse, de kategorier og grænser, der bliver dem til del. Endvidere ser jeg på, fra hvilke køns- og etnicitetspositioner, det er muligt og på hvilke køns- og etnicitetskategorier, der konstrueres. ${ }^{4}$

\section{UDVIKLING GENNEM DELTAGELSE}

Den asymmetrisk positionering mellem de "etniske danske" og de "etniske andre" influerer på asylansøgernes mulighed for indflydelse og deltagelse i deres eget liv. I asyllejren tilbydes de 13 - 16 årige 3 timers undervisning 4 dage om ugen i centerskolens uddifferentierede klasse. For de 16-18 årige og opefter er der hverken adgang til skole eller arbejde. For de 13 til 18 årige er der ungdomskole to timer to gange om ugen. Resten af tiden går for en stor dels vedkommende med at sove, spise og "hænge ud" året rundt. Det er per se et meget begrænset mulighedsrum, der bliver de unge til del. Det kan resultere $i$, at deres sociale praksisser forsimples, reduceres eller sågar afvikles. Men hvis hverdagen udfyldes med muligheder, mål og perspektiver kan det forholde sig omvendt. Er der en chance for at deltage, øve indflydelse og bidrage kan man tale om udvikling fremfor afvikling (se også Højholt 1996). Udviklingsmulighederne stiller sig forskelligt alt efter, hvilke kategorier, positioner og handlerum, man har adgang til og alt efter, hvordan disse kategorier, positioner og rum spiller sammen og/eller skygger for hinanden. Ved at tænke "twice", dvs. ved at tænke såvel etnicitets- som kønskategorier ind i mit udviklingsbegreb bliver det muligt at udpege de positioner, hvorfra det i højere grad er muligt at deltage og "at gøre noget". Det gxlder især for de bosnisk-serbiske unge, som nationalt og lokalt er positioneret betydeligt bedre end "resten". De bosnisk-serbiske unge har f.eks. adgang til det danske skolesystem. Endvidere kan man se en differentiering af den etniske andethed i forhold til de somaliske unge, som gennemsnitligt hurtigere får svar på deres asylansøgning og som derfor ikke i samme grad er mærket af den institutionalisering, der finder sted. Desuden gælder det unge, som har skoleopgaver (dvs. de 13-15 årige) og/eller unge, som deltager i en daglig husholdning, dvs. fortrinsvis de unge kvinder. En anden vigtig akse er, hvilke rum 
(og dermed kønnede positioner), man har mulighed for at deltage i og på hvilke måder, disse muligheder stiller sig. Her viser det sig, at skellet mellem privatssfæren og den offentlige sfære har betyde-lige kønsspefikke dimensioner. Etnicitets- og kønskategorierne kompliceres yderligere ved at gennemkrydses og spille sammen med endnu to akser: Den subjektive forholden og asylopholdets varighed. Udviklingen gennem deltagelse omfatter også de unge, som ikke forholder sig passivt til deres position, men i højere grad selv positionerer sig i en mere favourabel position ved "at gøre noget". "It's important to do some-thing", svarede 13-årige Ahmet på spørgsmålet om, hvorfor han hele tiden reparerede cykler. Det samme svar blev givet af flere af de unge, da jeg spurgte dem, hvorfor de deltog i fotoprojektet. De forsøgte "at gøre noget", at skabe bevægelse og at undgå stilstand. Endeligt afhænger deltagelsesgraden af, hvor længe man har opholdt sig i asyllejren, hvor lang tid man har ventet $i$ transit. I det følgende uddybes de ovennævnte komponenter yderligere med særligt fokus på køn og etnicitet.

\section{KØNNEDE POSITIONER OG} DELTAGELSESSTRATEGIER

"At gøre noget” kan foregå såvel individuelt som kollektivt, og det kan foregå fra forskellige positioner. Det făr stor betydning for flere af de unge "at gøre noget" sammen med og for andre, at konstruere og indgå i fællesskaber. Ved etableringen af kærlig-

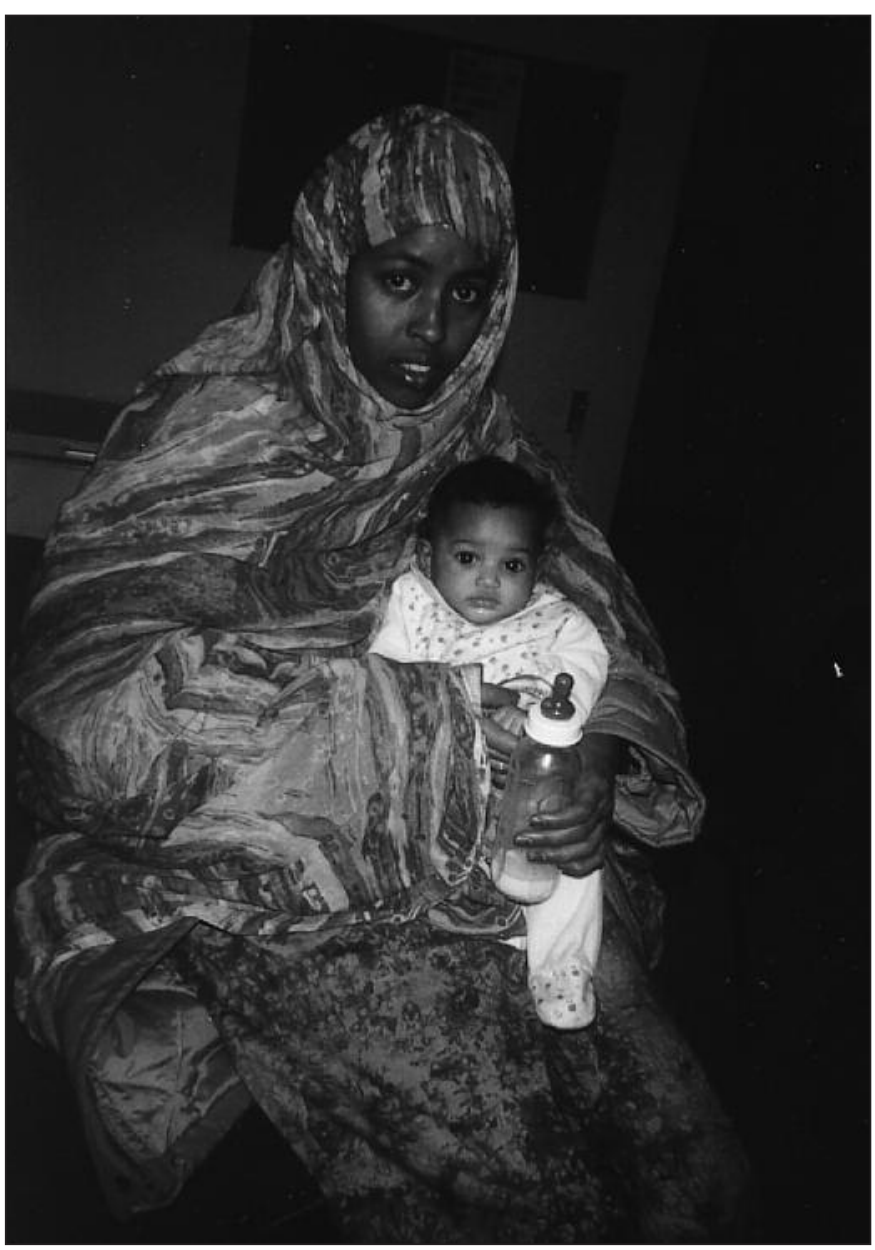


hedsforhold, venskaber og fællesskaber forsøger de unge at etablere en form for intersubjektivitet og bliver derigennem selv subjekter. En strategi er at holde sig til folk med samme sprog eller nationalitet som een selv. Det kan ikke bare forklares med racisme, men må også forstås således, at man aktivt forsøger at skabe en position og en (inter)subjektivitet. En anden strategi er at påtage sig ansvar for ledsagere, forældre, søskende eller andre børne og unge i lejren. Begge strategieksempler har kønnede fortegn.

\section{FRA EN POSITION}

\section{SOM UNG KVINDE/PIGE}

På mange andre centre har beboerne end ikke den daglige husholdning som ansvarsområde. I børne- og familiecentret er det muligt selv at varetage husholdningen, og den strukturering af dagligdagen kan fă betydning for udviklingen af kønnede handlemåder samt for kønnede udviklings- og afviklingsprocesser.

Her tænker jeg især på to unge piger, der i deres hverdag varetager en række (huslige) opgaver. Det interessante er, at der i samme praksis både ses aspekter af overskridelse og reproduktion af kønnet og etnisk ulighed. De deltager i, har indflydelse på og bidrager til en social praksis og dermed til opretholdelsen af deres eget liv. De laver mad, syr tøj, passer børn og gør rent. De har såvel en opgave, som en funktion i lejren. Deres handlemåder kan betyde, at uligheden i de mere traditonelle kønsmønstre reproduceres. Samtidig er de positioneret og positionerer sig på en måde, der indebærer udviklingsperspektiver. Og måske vigtigst, de har et (fremtids)perspektiv på deres liv, hvor det nuværende livsafsnit er en del af en fortsat livsbane. De bliver positioneret som husmødre, og det er på sin vis lidt ligegyldigt, om den tilhørende læringsog udviklingsproces finder sted i eller udenfor lejren. De har forbilleder $\mathrm{i}$ form af de voksne kvinder, som efterhånden overtager ansvaret for familien i asyllejren, og gennem forskellige aktiviteter holder sig i bevægelse. Dermed forhandler de to piger sig frem til (køns)identiteter, der kan give mulighed for deltagelse $i$, indflydelse på og bidrag til deres egen livssituation,. Det bliver muligt for de unge kvinder at etablere en position som betydningsfulde indenfor lejrens rum. (Danske) professionelle vil ofte kritisere det forhold, at en 13-årig pige påtager sig husholdningen for hele familien: Hun skal jo have lov at være ung. Men spørgsmålet må være, om det ikke også kan være godt for de unge at deltage og bidrage til såvel deres eget som andres livsopretholdelse. At have en funktion og en mening, der kan give dem et udviklingsperspektiv på deres liv.

\section{FRA EN POSITION SOM UNG MAND/DRENG}

De unge mænds deltagelse og bidrag er derimod yderst begrænset. De har ingen opgaver, og deltager f.eks. ikke i en daglig husholdning. De har intet ansvar, ingen funktion og ingen perspektiver på, hvad de kan udvikle sig mod. De unge mænd befinder sig i et vakuum, hvor de ikke har de muligheder, børn, unge og voksne ellers har. I såvel deres respektive hjemlande som i det øvrige Danmark (asyllejrene undtaget) ville der være inkluderet et udviklingsperspektiv på deres liv. De ville være igang med at forlade barneverden og på vej til at finde en "hylde" og en måde at deltage i voksenverden. Men i asyllejren er der hverken "hylder" eller måder, hvorpå man kan "være på vej". De unge mænd fra 16-18 år er nemlig ikke på vej. De venter blot,og set udfra deres eget perspektiv er det begrænset, hvad de som asylansøgere kan gøre for at prikke hul på vakuumboblen og få et perspektiv, der rækker videre. De har ikke samme muligheder som "etniske danske", fordi der eksisterer en nærmest uoverskridelig kløft mellem "etnisk danske" og "etniske andre". Heller ikke de voksne mandlige 

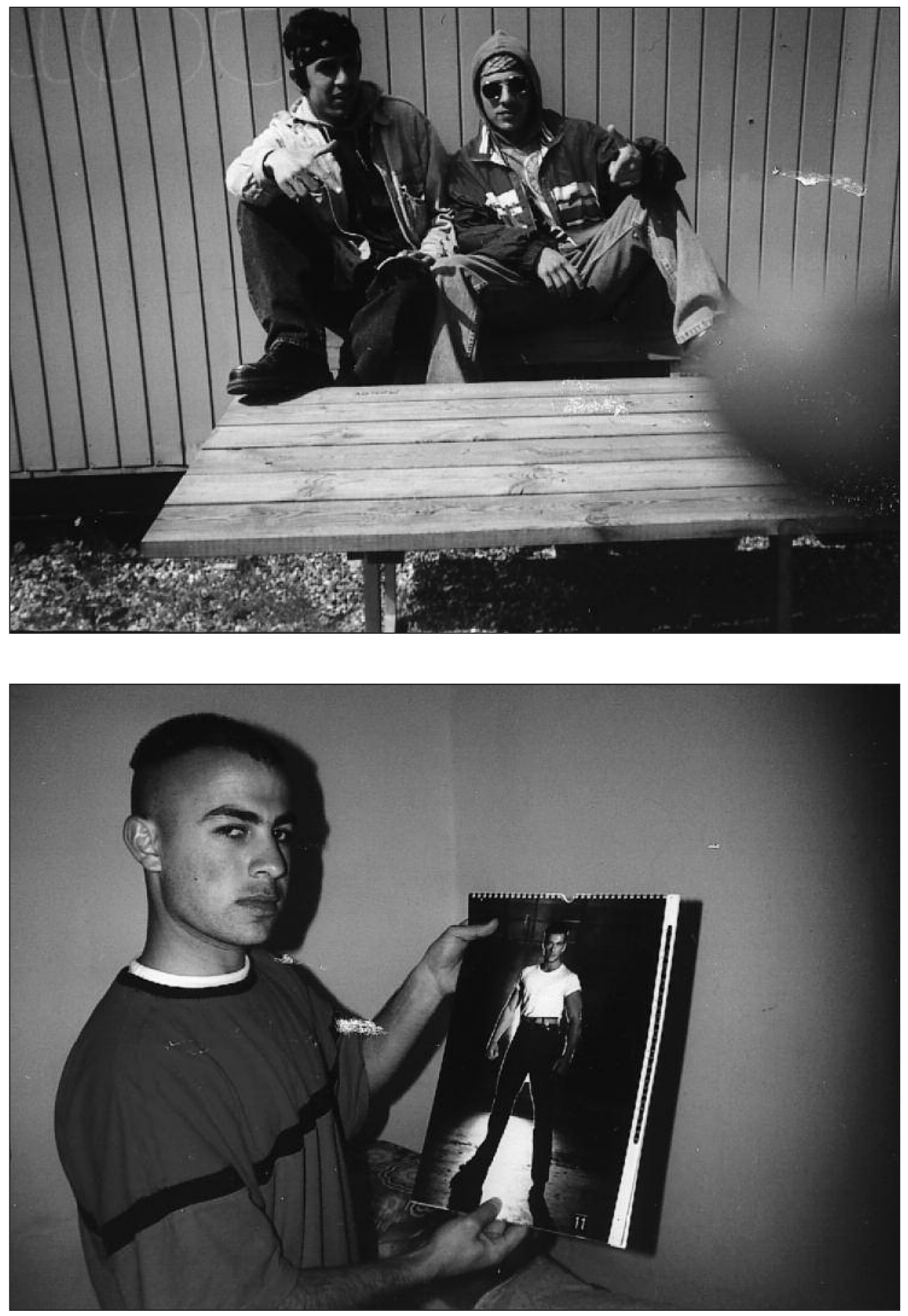
beboere synes særlig forbilledlige for de unge: De voksne mænd er afhængige af en professionel praksis. De er udleveret til deres livsbetingelser, laver ingenting og går mere og mere i opløsning. I børne- og familiecentret er det særligt de unge mænd, der selv må konstruere livs- og udviklingsperspektiver eller hente sådanne perspektiver ind fra et tredie sted og rekontekstualisere dem.

\section{KØNNEDE KONSTRUKTIONER AF (SELV)REPRÆSENTATIONER}

Der er qua asyllejrens andet- og klientgørelsesprocesser en tendens til, at man definerer sig selv og andre udfra, hvad man er, og hvordan man fremtræeder i nuet fremfor, hvad man beskæftiger sig med, eller hvad man er på vej til at blive. Man bruger de forhåndenværende brugbare markører, der kan sætte forskelle. I asyllejren kommer det derfor til at spille en væsentlig rolle for opfattelsen af een selv og andre, om huden er sort eller hvid og/eller religionen islam eller kristendom. Endvidere bliver det et afgørende element i selvopfattelsen, at man er asylansøger og en "etnisk anden" med en ikke-dansk nationalitet. I forsøgene på at overskride ulighed og marginalisering forsøger nogle af de unge at omdefinere sig til noget andet end (blot) asylansøgere fra et tredjeverdens land. Gennem en række forskellige handlestrategier forsøger de at åbne deres verden og får herigennem konstrueret en række alternative (selv)billeder.

Positioneret som såvel ung kvinde som unge mand forsøger flere af de unge at omdefinere sig selv ved at afprøve forskellige identiteter. Man forsøger med andre ord aktivt at konstruere et nyt selvbillede ved (som man kan se på diverse fotos) f.eks. at klippe håret, ændre kroppens overflade og påklædning, tage det islamiske hovedtørklæde af eller på. Disse strategier er tegnsættende praksisser (Hall 1997), der sætter aftryk i verden. Det er praksisser, der kan gøre en selv og andre opmærksom på, at man er til, at man er noget, at man bevæger sig. Med disse "måder" forsøger man at få indflydelse på og bidrage til sit eget liv.

\section{FRA EN POSITION SOM UNG MAND/DRENG}

Efter de første billedfremkaldelser var jeg meget forundret over mængden af turistbilleder. I materialet er der talrige billeder, som ikke umiddelbart har hverdagslivet i asyllejren som motiv, men derimod forestiller rejser og ekskursioner ud af lejren. Man møder den sorgløse turist (måske en smart italiener) på strøgtur, på skovtur, i Frederiksberg Have eller foran Københavns lysreklamer iført en skødesløs cowboyjakke og mørke solbriller. Et andet yndet motiv er de unge placeret foran de tilstødende bosnierboliger eller foran store biler, som de er på vej til at "låse op". Endeligt byder det empiriske materiale på en del billeder af de unge i personalestuen i gang med at tale i personalets telefon, anvende personalets kaffemaskine eller kigge i papirer forbeholdt medarbejderne osv. Ved gennemsyn af disse billeder genhører jeg replikker, jeg har oplevet under min deltagerobservation såsom "min gode ven, Anders" (som er centermedarbejder), og jeg genser en række situationer, hvor de unge forsøger at skabe nogle meget personlige og private bånd mellem ulige parter, dem selv og personalet.

(Billed)konstruktionerne af de unge mænd som værende noget andet end asylansøgere kan måske umiddelbart minde om det fænomen, man i psykoanalytiske termer vil kalde en ubevidst fortrængningsmekanisme. Men ved nærmere analyse af konteksten og ved at spørge de unge selv, hvorfor de tager turistbilleder i forlystelsesparker fremfor af hverdagslivet i asyllejren, viser det sig, at deres handlemåde er udtryk for et aktivt og relativt bevidst valg af en refleksions- og repræsentationsmåde, der foregår $i$ et tempo og med en intensitet, som de unge selv vælger. De doserer selv, hvad og 
hvor meget de vil konfronteres med og reflektere over.

Forhandlingerne mod andre identiteter end asylansøgerens kan pege på, at de unge mænd forsøger at overskride de grænser, en placering i et multietnisk center og de interne positioner i centret sætter. Kontekstualiseres motiverne kan de pege på, at fotograferne forsøger at konstruere alternativer til deres hverdag som asylansøgere. Det er gennemgående, at de alternative konstruktioner indebærer perspektiver, som ikke refererer sig til den afhængige asylansøgers hverdag. Ved at konstruere og vælge andre (etniske) identiteter end asylansøgerens fra den tredje verden giver de unge mænd sig selv et nødvendigt udviklings- og fremtidsperspektiv. De identiteter, de unge konstruerer alternativer udfra, er placeret i bedre positioner end asylansøgere, har flere handlemuligheder og er mindre marginaliserede: Der er på politisk plan en større velvilje overfor de bosniske asylansøgere. De kategoriseres som europæere, dvs. tættere på “Os" og må f.eks. arbejde og gå i skole. Turisten er den frivilligt rejsende, som kan tage hjem og leve normalt igen. Den, som de "etniske danske" inviterer via farverige brochurer, modtager med åbne arme og bygger fashionable bygninger til. Personalet er de "etniske danske" for hvem, det meste er muligt og for hvem afmagt, umyndiggørelse og andetgørelse er andres lod. En personalestrategi, som de unge mænd bruger, er at tilkæmpe sig særlige opgaver eller privilegier såsom at optage festbånd på personalets anlæg eller formene andre børn og unge adgang til arrangementer (f.eks. ved at barrikadere døre), man selv deltager i og i sammenhæng hermed at manifestere sin særstatus fremfor andre asylansøgere. Identifikation med kontrolinstansen er i øvrigt et meget almindeligt træk i totale institutioner såsom hospitaler, fænglser og KZ-lejr (Goffman 1961). Det er typisk, at de unge anvender personalet som brugbare identifikationsfigurer og som stabiliseringsfaktorer, fordi forældrene efter- hånden mister deres funktion i lejren som såvel voksne. Paradokset er, at de unges identifikation med personalet samtidig er en undergravelse af deres eget familixre netværk, hvilket igen resulterer i, at de professionelle "tager over" og igen reproducerer de træk, der umyndiggør de voksne, som så igen.... Identifikationen med personalet kan derfor på langt sigt være en strategi, der lukker verden fremfor at åbne den.

De unge mænd oplever deres "egne" voksne mænd som passiviserede, udeltagende og umyndiggjorte. De unge kender kun få "etniske andre", som har opholdstilladelse. Når jeg spørger dem, hvad man kan lave, når man har fået asyl, har de unge som regel ingen anelse. En enkelt har dog: De flygtninge, han kender, der har fået asyl, laver det samme som han selv. Ingenting. De unge mænd kan være $\mathrm{i}$ asyllejrens offentlige rum, men der er på en eller anden måde ikke en funktion eller en plads til dem her. De kan være her, men blot som nogle, der "hænger ud". Identifikation med andre end asylansøgere og distancen fra asyllivet kan ses som et forsøg på at åbne verden ved at genetablere en (fremadrettet) livsbane. Et forsøg på at blive noget andet end asylansøgende, fordi det kan være svært at holde sig et fremtidsperspektiv for øje i en kontekst, hvor uvisheden om fremtiden er så fremtrædende, men hvor visheden om, at man kategoriseres som undermenneske og “ikke tæller med”, er så nærværende.

\section{FRA EN POSITION SOM UNGE KVINDE/PIGE I LEJREN}

"For a black women to be different is to be what she is not expected to be", skriver Heidi Safia Mirza (1997). Og det er precis den problemstilling, jeg sad med, da jeg fik fremkaldt filmene fra 13 årige Aisha fra Somalia. Aisha kategoriseres som en sort, etnisk anden asylansøger, men hendes billeder fortæller en langt mere bredspektret historie.

Aisha i det offentlige rum i tækkelig 


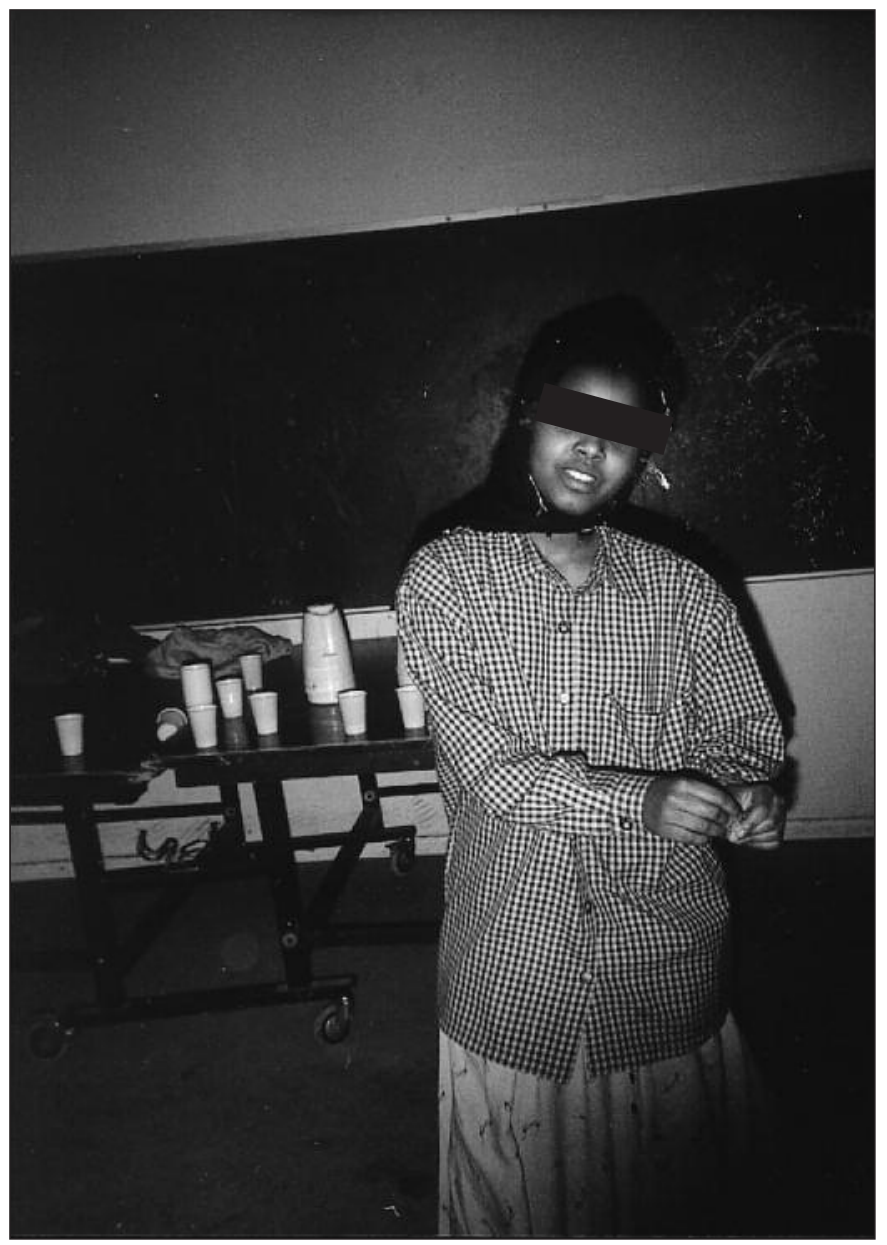

skjorte og nederdel, der dækker krop, ankler, håndled $\mathrm{og}$ hår. Aisha i hel figur på værelset i traditionel somalisk klædedragt. Igen på værelset. Denne gang i cowboybukser og undertrøje med bare arme. Aisha i et halvtotalperspektiv. Et andet tidspunkt. En anden dag? I stramme cowboybukser og blomstret bh. Stående i en fotomodellignende positur. Altid vendt mod kameraet. Poserende og bevidst om iscenesættelsen.

Aisha har taget ca. 250 billeder af sig selv og af livet i lejren. Billederne ovenfor er en del af hendes bud på, hvordan det er at leve i en dansk asyllejr og hvilke selvopfattelser, der kan komme til udtryk der. Jeg havde ikke forventet, at en asylansøger ville tage den slags billeder, når vedkommende skulle fortælle om, hvordan det var at bo i en asyllejr. Jeg havde heller ikke forventet at se en ung somalisk pige optræde i så forskellige og undertiden afklædte udgaver. Aishas repræsentationer var ikke tilstede på hverken mine hverdagskort eller på de videnskabelige kort, jeg indtil da havde set over asylansøgerlandskaber eller somaliske kvinder. Aisha passede ikke ind! Ved gang på gang at forhandle representationer af sig selv på ny har hun sat spørgsmålstegn ved, om man kan forstå sociale kategorier som "køn", “etnicitet" og “asylansøger" som lukkede og entydige. På Aishas snapshots ser man ikke den stereotype asylansøger. Eller ofret for den etniske majoritets styring, kon- 

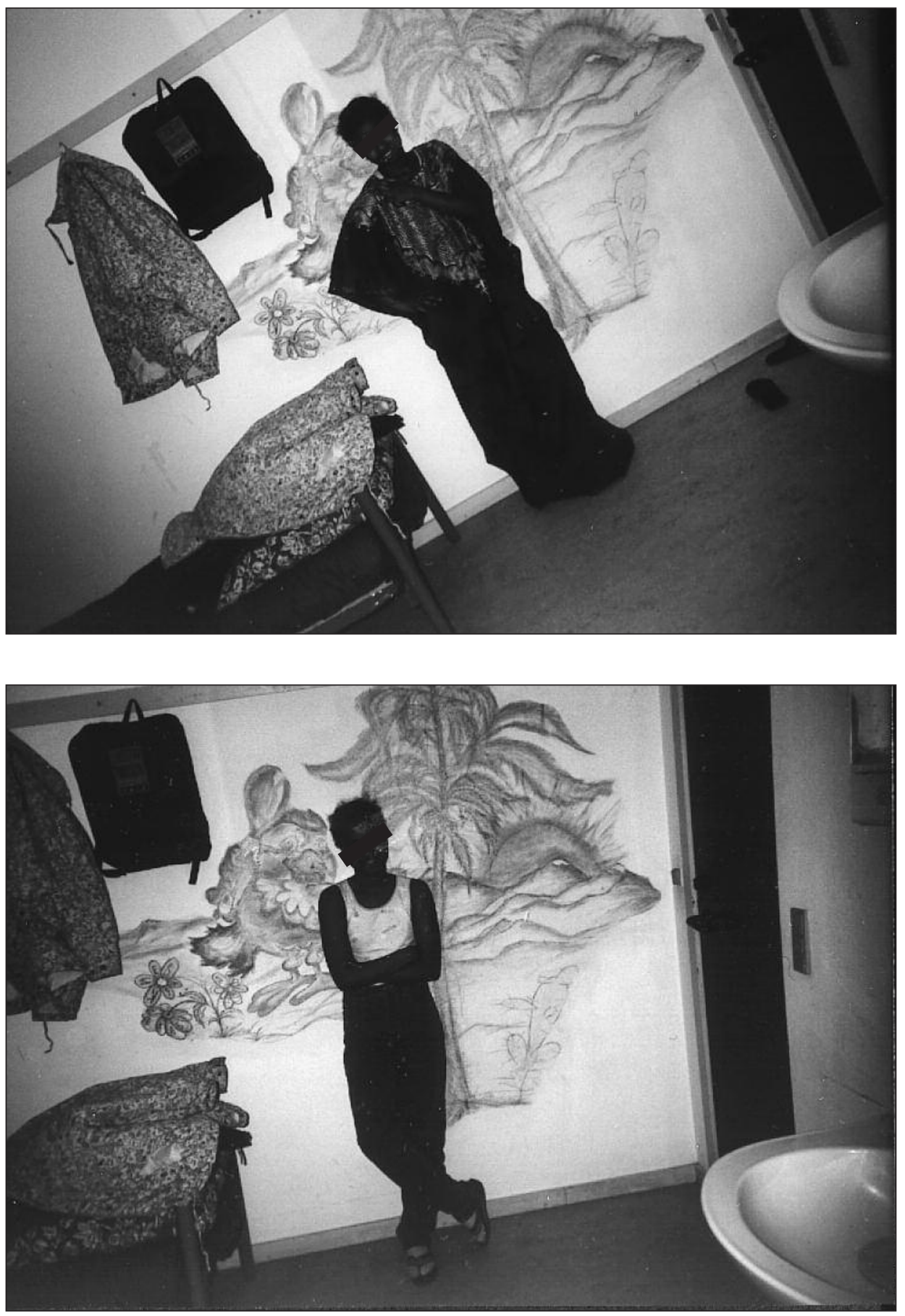


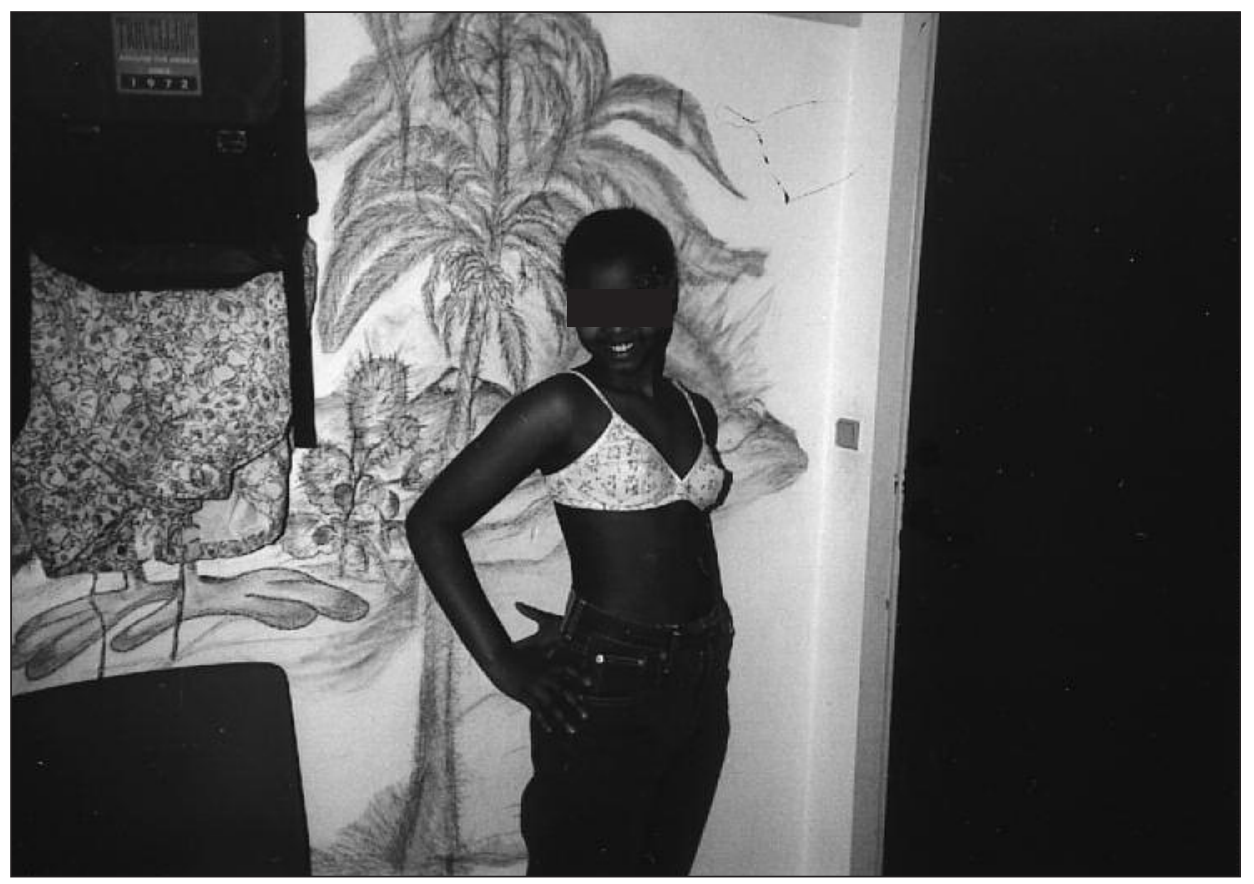

trol og marginalisering. Det er ikke stereotypen af den muslimske kvinde, der portrætteres, hvis jeg ser på billederne som en serie eller fokusere på billeder taget i de private rum. Derimod ser vi et subjekt, der aktivt forhandler sin livsituation og sin subjektivitet og overskrider de grænser en placering i samfundets margin, som oftest behxftes med. Hun er en anden "Anden". Forstået på den måde, at hun også gør noget andet og optræeder anderledes end mange af de "etniske andre" asylansøgere. Igennem billederne udtrykker Aisha refleksion over og forhandling af positioner bundet op om såvel køn, etnicitet og asylansøgerstatus. Med Rosi Braidottis (1994) begreb kan Aishas praksis forstås som nomadiske bevægelser, der krydser vores kort over etablerede kategorier og positioner. Hun kan forstås som et nomadisk subjekt i den forstand, at hun mobliserer sig, krydser grænser for det gængse. "Think twice" eller mere, førend du kategoriserer hende.

Aisha har formået at indfange mangfoldighed og ændring i såvel sin medforskningstilgang som i sine produkter. I hendes representationer ser man ansatser til at overskride den etniske andethed og identificere sig med et "normalt" liv udenfor lejren. Man ser en insisteren på at være den første, den handlende, den normale og dermed ansatser til konstruktionen af alternative selvbilleder. Men det er vigtigt at være opmærksom på to forhold, der viser, at dette ikke blot er et spørgsmål om, at Aisha konstruerer på må og få, men netop på positionerede betingelser: For det første har Aisha i forhold til mange af de andre medforskere kun opholdt sig kort tid i lejren, hvorfor hun ikke i samme grad har været eksponeret for afviklingsdynamikker. For det andet er alle de billeder, der fanger fler- 
heden af hende, taget $\mathrm{i}$ de private rum. Ganske kort efter, at hun ankom til lejren begyndte hun konsekvent at bære slør i de offentlige rum. For i den offentlige sfære er spektret for kvinders representationer knap så bredt. I asyllejrens offentlige rum ser man ikke forbi kroppens kønnede tegn. ${ }^{5}$ De forhandles til stadighed med forskellige positioneringer, muligheder og begrænsninger til følge. Især forhandles kvindekønnet som markør for kultur og traditioner (Mørck 1998). Det er tydeligt, at familierne/ledsagerne til en given pige - og sågar landsmænd, som udover fælles nationalitet og religion ikke har nogen forbindelse til pigen - ønsker at beskytte de muslimske pigers dyd i det kristne Danmark. Ikke blot for pigens skyld men også for at markere tradition og kultur i det multietniske og religiøse rum, som asyllejren også udgør. Eksempelvis var det trods forældrenes accept af forholdet meget vanskeligt for en ung kosovoalbansk kvinde at have et forhold til en ung palæstinensisk mand. En landsmand holdt øje med hende, truede hende og ringede rundt til andre asylcentre for at indvie andre kosovoalbanere i den "uanstændige" relation. En konsekvens af markørpraksissen kan være, at der sættes stramme regler for en unge piges omgang md andre, hvorfor nogle af dem bliver meget isolerede og til tider vælger at optræde endnu mere "muslimsk kvindeligt" i det offentlige rum, end da de ankom. De tager tørklæde på: Nogle i bogstaveligste forstand, andre i overført betydning.

\section{STRATEGIER OG REPRÆSENTATIONER, DER OPLØSER OG BRYDER}

Et forhandlingsindlæg, som også åbner verden og bidrager med alternativer til præasylets perspektivløshed, kan kaldes "at omdefinere andetgørelsens stigma til varemærke". Det er praksis, der gør den "etniske anden" til en selvvalgt strategi fremfor et udefrakommende, prædeterminerende stempel. Fra at være en "etnisk anden", et afvigende objekt for andre udvikler man sig til et subjekt med etnicitet for sig selv. Man er, hvad man er, og det er man på stolt af. Man begynder at gøre meget ud af sin religion, man forsøger at signalere sin særegenhed og subjektivitet gennem tegn som religiøs praksis, musik, tøj og væremåde.

Det er en meget benyttet strategi blandt især unge mænd fra Somalia, men også blandt enkelt unge mænd fra Mellemøsten at identificere sig med og handle ligesom andre udstødte og marginaliserede grupper. Især den afroamerikanske scene synes at have stor slagkraft blandt de unge mænd, og deres tegnsættende praksisser ses i en række overflader. De unge iklæder sig deres symboler, tøj, bruger musikken, slang og "the street-attitude". De unge mænd kalder sig selv og hinanden "nigger", rapper med på de afroamerikanske rappere Snoop Doggy Dog og Ice Cubes racistiske og sexistiske budskaber, ser film som "Boyz ' $n$ ' the hood" om sorte bandemedlemmers liv i Los Angeles' South Central-kvarter.

I forsøget på at etablere et alternativ til asylansøgerens magtesløshed og reformulere det at være marginaliseret, genfortolker de unge mænd således deres kulturelle baggrunde og deres etniske andethed, og de iblander globale kulturstrømninger i en dansk (lokal) kontekst. ${ }^{6}$ Hver enkelt sammensætter forskellige kulturelle elementer på sin måde, og der er i disse sammensatte konstruktioner både fællestræk og noget unikt for hver enkelt. Det er en praksis, som giver mening og sammenhæng i den enkeltes vurdering af egne livsbetingelser, og samtidig en "måde", som har sociale aspekter, idet man deltager i, bidrager til og har indflydelse på en fælles virkelighed. Det er ikke på trods af asyllejrens betingelser, at de forbliver "etniske andre" eller bibeholder deres kultur. Det er netop pga. af handlekonteksten, at de bliver det "etnisk andre" og dyrker en særlig etnisk andethed.

Det er vigtigt at være opmærksom på, at de unge mænd anvender strategierne i det offentlige rum, og at brugen af dem under- 
tiden er højrøstet og konfliktskabende, idet de udfordrer de etablerede magtfordelinger. Børne- og familiecentrets unge mænd har i højere grad end lejrens unge kvinder mulighed for at bidrage med alternative og konfliktuelle repræsentationer i det offentlige rum. Jeg har ikke set "fra stigma til varemærke"-strategien benyttet af de unge piger, der boede i lejren. Derimod har jeg set dem praktiseret af en gruppe asylansøgende piger fra et andet center, der var på besøg. I deres praksis sås koderne for, at det er muligt trods et kvindeligt kropstegn. At muligheden for at gå mod mere mangefacetterede og kulturelt heterogene kvindebilleder $i$ det offentlige rum afhænger af lejrens interne strukturer, fik jeg øje på ved at se nærmere på de besøgende pigers praksisser. Gæsterne kom fra et asylcenter, hvor der kun bor uledsagede børn og unge. Det er derfor endnu mere institu- tionaliseret og med en endnu mindre privatsfære end i børne- og familiecentret. F.eks. har kontaktpersoner en større indflydelse på den enkeltes livspraksis, når der hverken er for-ældre eller ledsagere, og beboerne har ikke egen husholdning. De unge pigers tøj, fri-sure, kropssprog og verbal ytring (hvor ordet "fuck" optrådte mellem hvert andet ord) var klart inspireret af den måde, hvorpå afroamerikanere fremstilles i Hollywoodfilm. De unge piger viste i deres handlen og forholden, at de som deltagere i det offentlige rum og $\mathrm{i}$ forhold til de betin-

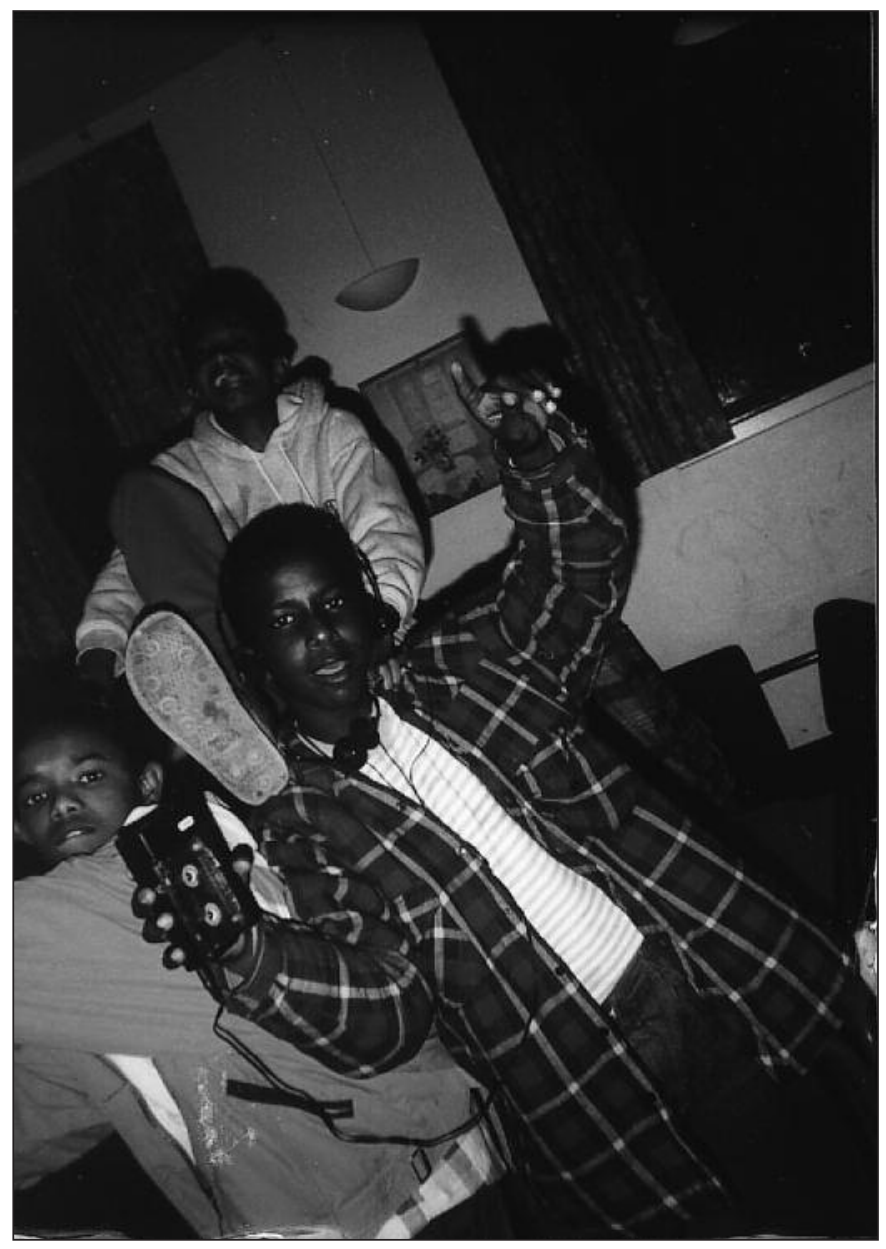


gelser, der ligger her, også har mulighed for at jonglere med kulturelle strømninger og danne alternative og kontroversielle representationer i den offentlige sfære. Det var også bemærkelsesværdigt, at det var disse unge piger, der i samspillet med de unge mænd, positionerede sig som de magtfulde og definerende.

\section{"THINk TwICE"}

"To be inappropriated means to be dislocated from the available maps specifying kinds of actor and narratives", skriver Donna Haraway (1992). I fotoprojektet blev det muligt at bringe nye kort, nye aktører og nye (selv)repræsentationer på banen. Præmisserne var at tænke "twice", dvs. at tænke dobbelt, at gentænke og at tænke både-og på flere niveauer: 1) at etablere et forum for medforskning og dialog, 2) at gentænke den empiri, "der ikke lige passer ind" til vigtige ledetråde og 3 ) at lade flere kategorier spille sammen $i$ analysen.

Med de unge mænds og kvinders nye forhandlingsindlæg kan førstehed, andethed og ulighed forhandles på ny, og de unges praksis- og identitetsprojekter viser sig at have politiske implikationer $\mathrm{i}$ forhold til såvel køn som etnicitet. Hverken andetgørelser eller grænsedragninger siver bare ned til de unge eller reproduceres passivt. Det unge er derimod aktører, der forholder sig til og forhandler deres livssituation. Konstruktionen af kønnede og (andre) etniske identiteter i asyllejren er måder, hvorpå man genindsætter sig selv som deltager $\mathrm{i}$ sit eget liv. Set i det perspektiv er der tale om såvel udviklingsmuligheder som overlevelsesnødvendigheder.

\section{NOTER}

1. I forskningsdesignet indgik engangskameraerne og et medforskningsperspektiv som det væsenligste omdrejningspunkt suppleret med deltagerobservation, kvalitative interviews og læsning af skriftligt materiale. I overvejelserne om brug af fotos var det især muligheden for perspektivskifte og dialog, der var fremtrædende. Med et kamera kan man i overført betydning filme i to retninger. Ud på verden og ind på beskueren. Når filmen fremkaldes og billedet kopieres er situationen "taget ud af øjnene” på fotografen og har fået sit eget liv. Medforskning i form af fotografering kan betragtes som en lærings- og udviklingsproces, hvor det at tage billeder af sit eget liv muliggør et perspektivskifte. Fotografier muliggør en dialog mellem fotografen og omverden. På tværs af sprogforskelle. De kan videreformidles, og det giver de mennesker hvis liv, der studeres, en direkte indflydelse på det repræsentative resultat. Ved at indhente de unge asylansøgeres perspektiver på deres liv i lejren gennem fotografering blev det $\mathrm{i}$ projektet muligt om ikke at ophæve så i alle tilfælde krydse skellet mellem forsker og udforskede, og på den måde udfordre og bringe andre stemmer og andre representationer end forskerens på banen. (Staunæs 1995;1998b).

I min medforskergruppe deltog 11 børn og unge mellem 8 og 18 år. De unge skød godt 2500 billeder. I artiklen beskæftiger jeg med de data, der omhandler asyllejrens unge mellem 13 og 18 år, og jeg har udvalgt en mindre gruppe fotos, der illustrerer artiklens pointer.

2. Dvs. en lejr for asylansøgere, som ikke er fra Bosnien - bosniske serbere kan dog godt opholde sig i en multietniske lejr, hvilket var tilfældet i det pågxldende børne- og familiecenter.

3 . Der er en stor forskel på ideen om en etnisk essens, forstået som noget særligt etnisk/kulturelt iboende bestemte mennesker og så en påpegning af de måder, hvorpå etnicitet bliver konstituteret gennem forskellige bestemte sociale, institutionelle og samfundsmæssige formationer og forhandlinger (se også hooks 1993).

4. Det analytiske snit er foretaget udfra en forståelse af, at køn og etnicitet ikke er noget, man har eller er, men derimod noget aktører i sociale samspil konstruerer og gør ud fra bestemte positioner (se f.eks. Thorne 1993; Søndergaard 1996).

5. For dette begreb se Søndergaard 1996.

6. Stuart Hall (1992) har kaldt sådanne konstruktioner for hybride former for kultur og kulturel selvopfattelse. Det kan diskuteres om begrebet hybriditet er rammende, eller om det snarere fastholder en binær tænkning og ikke foregriber en mere 
multifacetteret sammensætning. I en dansk sammenhæng har Røgilds (1995) og Mørck (1998) skrevet om hybride identiteter.

\section{LITTERATUR}

- Afsar, H \& M. Maynard (1994): "Introduction to the Dynamics of "Race" and Gender." I Afsar, H. \& M. Maynard (ed): The Dynamics of Race and Gender - Some Feminist Interventions. Taylor \& Frances, London

- Agger, N.P. \& H. Andersen (1991); "Far, mor og børn. Organisation og desorganisation i behandlingssystemet." I Udkast nr 2. Dansk Psykologisk Forlag, København

- Bousquet, G. (1987): "Living in a State of Limbo. A Case Study of Refugges in Hong Kong Camps." I Morgan, S \& E. Cotton (eds): People in Upheaval. Center for Migration Studies, New York - Braidotti, R. (1994): Nomadic subjects. Embodiment and sexual difference in contemporary feminist theory. Columbia University Press, New York - Dansk Røde Kors Centerhåndbog - de Voe, D.M. (1981): "Framing Refugees as Clients." I International Migration Review. Vol. 15 No. 1

- Foucault, M. (1979): Disciplin and Punisbment..The Birth of the Prison. Vintage Books, New York

- Goffamn, E. (1961): Asylums. Essays on the Social Situation of Mental Patiens and Other Inmates.

Penguin Books, London

- Hall, S. (1992): "The question of cultural identity." I Hall, S. et al (ed): Modernity and its futures. Polity Press, Cambridge

- Hall, S. (1997): "The Work of Representation." I Hall, S (ed): Representation. Cultural Representations and Signifying Practices. Sage, London - Haraway, D. (1992): "The Promises of Monsters: A Regenerative Politic for Inappropriated Others." I Grossberg, L. (ed): Cultural Studies. Routledge, New York

. Harrel-Bond, B. \& E. Voutira (1992): "Anthropology and the study of Refugees." I Anthropology today. Vol. 8. No. 4

· hooks, b. (1993): "Postmodern Blackness." I

Williams, P. \& L. Chrisman (ed): Colonial Discourse and Postcolonial Theory. Harvester Wheatsheaf, New York

• Højholt, C. (1996): "Udvikling gennem deltagelse.” I Højholt, C. \& G. Witt (red): Skolelivets socialpsykologi. Unge Pxdagoger, København - Larsen, C. H.(1995): Det bosniske eksperiment.
Flygtningeliv $i$ mellemtiden. Det Danske Center for Menneskerettigheder, København

- Mirza, H.S. (1997): "Introduction: Mapping a genealogy of Black British feminism.” I Mirza, H.S. (ed): Black British Feminism. A Reader. Routledge, London

- Mørck, Y. (1998): Bindestregs-Danskere. Fortellinger om køn, generationer og etnicitet. Forlaget Sociologi, København

. Osterkamp, U. (1990): "Intersubjektivität und Parteinahme: Problemen subjekt-wissenschaftlicher Forschung." I Gekler \& Wetzel (Hrsg): Subjektivität und Politik. Verlag Arbeit und Gesellschaft, Marburg

- Shachak, O. (1986): "Componentiality as a Survival Strategy in a Total Institution: Case Study of a POW in Solitary Confinement in a Syrian Prison." I Milgram, N.A. (ed): Stress and Coping in Time of War. Generalizations from the Isralien Experience. Brunner/Mazel Publishers, New York - Staunæs, D. (1995): "De "Andre" i skiftende perspektiver. Om en udforskning af flygtningebørn i en dansk asyllejr." I Udkast nr l. Dansk psykologisk Forlag, København

- Staunæs, D. (1997): "Når Ali gør noget andet end de "etniske andre"." I Arenas, J. (red): Interkulturel psykologi. Hans Reitzels Forlag, København

- Staunæs, D. (1998a): En “Anden” bruger? Om behandling af misbrugere med etnisk minoritetsbaggrund. En CRF-publikation. Center for Rusmiddelforskning, Aarhus Universitet. Århus

- Staunæs, D. (1998b): Transitliv. Andre perspektiver på unge flygtninge. Politisk Revy. København.

- Søndergaard, D.M. (1996): Tegnet på kroppen.

Køn $i$ akademia: Koder og konstruktioner. Museum Tusculanum, København

- Thorne, B. (1993): Genderplay. Girls and boys in School

- Tolman, C. W. (1994): Psyhology, Society and Subjectivity - An Introduction to German Critical Psychology. Routledge, London

\section{SUMMARY}

The Danish research on ethnic minorities have often been based on the "Great Narrative of Worridness". A narrative included with inappropriated and problematic others, as passive objects of marginalization. By "thinking twice" on several levels the article 
challenges this approach and makes it possible to present new representations of young asylumseekers. The text is based on a researchproject, where the traditional distinction between researcher and researched was blurred. Young asylumseekers cooperated as co-researchers and shot approximately 2500 pictures of their lives in a refugeecamp. Despites institutionalization the pictures and the way of doing coresearch showed new developments in the young asylumseeksers lifepossibilities, practices and identities, and demonstrated how these possibilities, practices and identities constitutes and are beeing constituted by gen- dede ethnicities and ethnic genders. The way of croissing bordes and desturing closed categories as "asylumseeker" and "ethnic other" truns out very differently depending on the positions as male or female. The article argues that the development of (self) representations and practices challenging the processes of othering are (political) survivalstrategies for young "ethnic others" living in an extrem position of marginaliszation.

Dorthe Staunæs er cand. psych. og ph.d.-stipendiat ved Interkulturel kommunikation, RUC. 